a nawet podstawy polskiej logopedii. Nie zapominajmy więc o tym, co było, by w przyszłości nie zapomniano o nas!". Wątek historyczny przewijał się przez większość wystąpień. Narastanie refleksji logopedycznej było m.in. tematem referatu S. Grabiasa z Zakładu Logopedii i Językoznawstwa Stosowanego UMCS. M. Jędrzejczak przedstawił fakty i źródła zwiazane z funkcjonowaniem pierwszych w Polsce poradni rehabilitacyjnych dla dzieci głuchych. Omówiono m.in. historię logopedii na Śląsku (M. Chęciek, I. Nowakowska-Kempna), poznańska myśl logopedyczną (K. Błachnio), opiekę logopedyczna (począwszy od dwudziestolecia międzywojennego) w Klinice Foniatrii i Audiologii AM w Poznaniu (A. Obrębowski), terminologię związana $z$ wadami wymowy na przestrzeni dziejów (A. Sołtys-Chmielowicz), międzywojenna nomenklaturę logopedyczną (E. Kuczyńska). Należy podkreślić, że 21 spośród 23 wygłaszanych na Zjeździe referatów wydrukowano w Logopedii 23 , którą wszyscy uczestnicy otrzymali przed rozpoczęciem obrad.

Wiele mówiono w Lublinie o zasługach „ojca polskiej logopedii" prof. L. Kaczmarka. Wyrażano żal z powodu Jego nieobecności na lubelskim Zjeździe i w związku z tym zredagowano list, w którym m.in. podkreślono olbrzymią rolę, jaką odegrał w rozwoju powojennej logopedii ${ }^{1}$. Niewątpliwym urozmaiceniem pierwszego dnia obrad byl, jak to zapowiedziano w programie, „pokaz popularno-naukowo-rozrywkowy", w którym przewodniczący PTL pokazał „drugą twarz", tzn. prezentując kilka prostych doświadczeń przypomniał uczestnikom Zjazdu, że z wykształcenia jest fizykiem.

W ostatnim dniu Zjazdu odbyło się Walne Zebranie Członków PTL, podczas którego wybrano nowy Zarząd Glówny. Przewodniczyć będzie mu nadal prof. B. Adamczyk.

Ewa Kuczyńska

\title{
Konferencja naukowa: Historyk nauk medycznych wobec inspiracji badawczych. Teoria i tradycja
}

W dniach 18 -19 października 1996 r. odbyła się w Poznaniu konferencja naukowa pt: „Historyk nauk medycznych wobec inspiracji badawczych. Teoria i tradycja”. Została zorganizowana pod protektoratem Instytutu Historii Nauki Polskiej Akademii Nauk i Fundacji Humanitas Et Scientia. Inicjatorem konferencji byl dr Jaromir Jeszke z Zakładu Historii Nauk Medycznych Akademii Medycznej im. Karola Marcinkowskiego w Poznaniu. Obrady odbywały się w Ośrodku Nauki PAN w Poznaniu przy ulicy Wieniawskiego 17. W konferencji uczestniczyli naukowcy zajmujący się problematyką historii medycyny z kraju, z Niemiec oraz przedstawiciele studentów.

W pierwszym dniu konferencji wygłoszono następujące referaty:

Jaromir Jeszke - Lekarz i historyk jako badacze dziejów nauk medycznych; Tadeusz Brzeziński - Historia nauk medycznych jako dyscyplina medyczna; Wojciech Wrzosek - Historia nauk medycznych jako dyscyplina historyczna; Bożena Płonka-Syroka - Niemiecka medycyna romantyczna w historiografii XIX i XX stulecia; Adam Paluch - Uwagi etnologa wobec historii medycyny;

${ }^{1}$ Profesor Leon Kaczmarek zmarł 26 października 1996 r, dwa tygodnie po Zjeździe Polskiego Towarzystwa Logopedycznego, którego dzialalność inicjował w 1963 r. 
Zbigniew Jastrzębowski, Tadeusz Srogosz - Świadomość metodologiczna polskich historyków medycyny po II wojnie światowej.

Obrady odbywały się na dwóch sesjach - przedpołudniowej i popołudniowej.

W drugim dniu obrad przedstawiono następujące tematy:

Jerzy Strojnowski - Historia medycyny wobec relatywizmu;

Peter Gorski - Kolektywy farmaceutów wileńskich i erfurckich (1820) widziane w kategoriach pojeciowych Ludwika Flecka (1896-1961);

Jan Nosko - Historia medycyny a historia zdrowia publicznego;

Włodzimierz Piątkowski - Inspiracje historyczne w badaniach socjologicznych nad lecznictwem niemedycznym.

Wszystkie wygłoszone referaty wywołały ożywione dyskusje. Szczególnie polemiczny okazał się problem zasygnalizowany przez dr J. Jeszke dotyczący relacji różnych sposobów spojrzenia na przeszłość przez historyków medycyny - w zależności od ich wykształcenia historycznego czy też medycznego. W konkluzji stwierdzono, że wartościowym jest fakt, iż historią medycyny zajmuja się przedstawiciele różnych nauk, a więc historycy, lekarze, socjolodzy czy etnolodzy. Umożliwia to różne ujęcie zagadnień historycznych. Prof. T. Brzeziński w swym wystapieniu wskazal m.in. na interdyscyplinarność historii medycyny. Mówil o dominacji biologicznego podejścia w historii medycyny. Przyznał jednak, że winno przeważać podejście holistyczne.

Wygłoszone referaty i dyskusje naświetliły w sposób rzeczowy, często nowatorski możliwości wieloaspektowego, interdyscyplinarnego ujmowania historii medycyny. Uczestnicy konferencji mieli ponadto możliwość zwiedzenia Muzeum przy Zakładzie Historii Nauk Medycznych Akademii Medycznej im. K. Marcinkowskiego w Poznaniu a także kórnickiego zamku.

Marek Szymczak

\section{Wychowanie a polityka. Tradycje i wspólczesność. Konferencja naukowa w UMK 7-8.XI.1996}

Instytut Pedagogiki oraz Zakład Historii Wychowania i Myśli Społecznej Uniwersytetu im. Mikołaja Kopernika w Toruniu zorganizował w dniach 7 i 8 listopada 1996 r. międzynarodowa konferencje naukowa na powyższy temat.

Tak sformułowany problem zachęcił nie tylko politologów i pedagogów różnych specjalności, ale także reprezentujących kilka ośrodków naukowych historyków dziejów powszechnych, historyków wychowania, fllozofów, fllozofów edukacji, socjologów, socjologów wychowania, historyków literatury, andragogów, a nawet reprezentantów dydaktyki medialnej i nowych technik kształcenia.

Dzięki temu udało się analizować nie tylko problematykę edukacji staropolskiej na tle przemian politycznych, rozmaite aspekty historyczne wychowania obywatelskiego, patriotycznego, w różnych przestrzeniach terytorialnych i różnorodnych obszarach geograficznych i politycznych, ale także:

- problemy roli nauki i państwa w wychowaniu;

- historyczne aspekty wychowania w zakresie zaborów w oświetleniu min. niektórych nurtów politycznych;

- zagadnienia edukacji wojskowej; 